\title{
The Aspect of Ethics Determined by Technological Impact
}

\section{Marcin PASKA}

Wroclaw University of Science and Technology, Poland, marcin.paska@pwr.edu.pl

\begin{abstract}
The aim of the article is to identify the issue of ethics as a major and crucial factor that accompanies the development and use of technology. The considerations related to the presented topic constitute an attempt to fill the research gap, in which ethics is perceived as an element that permeates and determines the process of adaptation and use of technology. This article points out on multidimensional technological impact that has influence on society and industry, which consequently also affects aspects of ethics. The content of this paper indicates necessity to build an appropriate ethical framework for the emerging technology, which in the field of science, despite its great dynamics, has started to develop relatively not long ago. This paper invites a discussion on how the development of technology and its actual use, could bring the discourse about ethics in field where the technology is implemented. Content of article is the very basis for further work.
\end{abstract}

Keywords: technology; adaptation; technological impact; ethics

\section{JEL Classification: O14}

\section{Introduction}

The processes of globalization and the development of new technologies unify the world. They seem to be strengthened by modern technologies and innovative solutions. The digital age is no longer the distant future, it is happening here and now (Hochut, 2017). This impact of technology seems to be what is changing the way how society operate (Harari, 2017). Each time when new technological are developed, new ethical issues are also introduced. (Park et al., 2019). Literature related with technology acceptance models (Davis, 1985; Ajzen \& Fishbein, 1980) try to present major factors that are responsible for technology adoption. Probably, a technology that does not meet the ethical criteria of a society is going to face a difficult process of acceptance, regardless of its potentially tremendous positive potential for long-term socio-economic development (Kuleshov et al., 2020). It brings with it opportunities and threats in the field of ethics. The present day is a dynamic development, in which information and knowledge determine a new stage of civilization progress, and the products of digital technology of this period create conditions for increasing human intellectual capabilities, which are the basis of creativity and innovation (Kowalczyk, 2017). Before the user actually uses a technology, he or she assesses the technology in terms of aspects such as the ease of use of the technology and the usability of the technology (Davis, 1985). Technology is to support the user in action, bring him better and faster solutions, reducing physical and mental effort during the task. The technology user is a form of relationship that is reflected in everyday life. The content of this article is a reflection on the ethical form of technology. 
The technology of itself, as Miller points out, is obviously morally and politically neutral. The author argues that it is neither good nor bad - while its actual use brings about moral or other values (Miller, 2020). As argued by Raab, there is now a confusing debate about the ethics of technologies that use data extensively and intensively (Raab, 2020).

\section{Technology Development}

Undoubtedly, the industrial reality that takes part in the accelerated digital transformation opens binary doors to new possibilities. Thus, it blurs its boundaries with virtual reality through automated production processes and applied robotics. The interest of industrial companies, intertwined with the global market economy, sees robotics and automation as a map leading to development. The effect of the development of the manufacturing industry, in its intended causative effect, appears to be the need to adapt and integrate new technologies. New technology and new resources are directly responsible for achieving success, which is to increase efficiency, flexibility, quantitative and qualitative efficiency in operation. Technology acceptance models should also take into account the ethical aspects of technology in terms of how technology shapes the image of today's world.

New computer technologies contribute to the intensification of the processes of globalization of economic activities. The effect of globalization, scientific discoveries, development and technological progress today has a significant impact on the manufacturing industry. It is being reflected that it is time to rethink the way industrial products are made. Hozdic and Butala (2020) indicate that a new approach to industrial production is needed that would solve new challenges and circumstances resulting from the escalation of uncertainty, dynamics and complexity of industry driven by turbulent market, political, economic and social conditions (Hozdić et al., 2020). Industry 4.0 is the use of intelligent processes and products supported by autonomous collection and points, and with comprehensive integration, resulting in smart payments, effective and efficient (Buer, 2018).

Scientists indicate that the manufacturing industry is currently undergoing a major change due to the rapid development and advancement of digital technologies and the reduction of technology-related costs (Monostori et al., 2016). The field of computer science, information and communication technologies, which are the pillars of cyber-physical systems, is progressing exponentially. Cyber-Physical Systems are systems of cooperating computing units that are in relation to the surrounding physical world and its current processes, providing access to data during its processing via the Internet (Kant, 2016). The dormant potential of the CPS can influence and permeate almost every aspect of human life. Concepts such as autonomous cars, robotics, smart buildings, smart electricity grids, smart manufacturing and implanted medical devices are just a handful of examples that are already in use. The modern philosophy of broadly understood production, which is identified with the fourth industrial revolution, takes the form of both a key and a door behind which innovative approaches to industrial production are to be hidden (Gajsek et al. 2019). At the same time, it should be borne in mind that along with opportunities, there are also risks and threats, also in the field of ethics. 
The fourth industrial revolution or Industry 4.0 is changing the strategies of companies and transforming their organizational structure, business models are changing, and value chains and supply chains are also transforming. The contemporary trend of changes directly affects processes, products, skills and relationships with all business stakeholders. In order to maintain a positive impact on business and society, it is necessary to properly manage the opportunities created by the revolution (Büchi et al., 2020). Modern processes are implemented with the support of a digital infrastructure that enables the collection of significant knowledge from supervised resources through the use of an intelligent approach to data control and fusion, as well as by adopting machine learning and continuous improvement procedures (Diez-Olivan, 2019).

\section{Technology Adaptation}

Professor Piotr Grajewski points out that the current stage of human development is characterized by a dynamic growth rate of the available set of knowledge and information. Additionally, the author emphasized the hitherto unknown - on such a large scale - pace of changeability of realities and conditions in which modern society lives. This pace is a cause of adaptation difficulties for many people. In fact, it results from the possibility of learning new techniques and using the potential of the achievements of modern civilization (Grajewski, 2016).

This content also allows to see the challenge facing global civilization in the perspective of overcoming difficulties of adapting changing social, political and economic models through the adaptation of technology. The previous industrial revolution that took place in the nineteenth century penetrates the essence of ethical issues, as this revolution created hitherto unknown conditions and problems that none of the then existing social, economic and political models could cope with.

Such a picture of the situation also resonates with the opinion of A. Toffler, who stated that the pace of changes in the contemporary world determines new qualitatively phenomena and problems, the essence of which cannot be fully described with the help of theories, truths and rules developed in past epochs. (Toffler, 1997) Therefore, the influence of technology forces man to develop completely new models and social, political and economic behavior. Models aimed at proper functioning, including ethical models for the resulting relationships.

The development of technology and information systems also determines the development of theories and models that are used to assess technology acceptance. Some of the most important works focused on this issue include The Theory of Reasoned Action (Ajzen \& Fishbein, 1980), The Theory of Planned Behavior (Ajzen, 1985), The Motiviational Model (Davis, 1991), Decomposed Theory of Planned Behavior (Taylor \& Todd, 1995), Innovation Diffusion (Rogers, 1962), Social Cognitive Theory (Bandura, 1986), Model of PC Utilization (Thompson, 1991), The Unified Theory of Acceptance and Use of Technology (Venkatesh et al., 2003), and Technology Acceptance Mode (Davis, 1985).

Summarized, these models aim to describe the motivational processes that mediate between system characteristics and user behavior. And as Professor Ejdys (2018) points out, technology acceptance can be identified as a process in which a stimulus is given being a 
function and possibility of the system, it interacts with people, acting on their motivation, thus prompting them to use the system. The indicated relationship leads to an answer that becomes the actual use of the system. Models contain a wide range of constructs, such as perceived ease of use, perceived utility, social norms, attitudes towards technology, and more, and try to capture the factors that determine the adoption of a given technology. Among the models mentioned, there is a reflection on the ethical dimension of these technologies, which may lead to the implementation of a new factor that the models do not take into account, which is trust in technology. When it comes to ethics and technology, scientists like Mark Ryan are asking, whether technology can be trusted, or instead, it should be place a greater emphasis on ensuring that organizations using technology, and individuals within those organizations, are trustworthy (Ryan, 2020).

Accepted technology enters into relationships with humans and shapes reality. Our lifestyle is changing as technology affects our lives, transforming the ethical standards of our behavior. The causative effect of technology acceptance is therefore the influence of technology on the way we operate today.

\section{Technological Impact}

Contemporary society, which consists of business practitioners, scientists, doctors, politicians, drivers and representatives of all other sectors of the economy, lacks a transparent understanding of how new technologies (emerging technologies) shape the developed social, economic and political models. When confronting the next progress of the industrial revolution, man should remain vigilant regarding the ethical relationship with technology and its explosive potential. Different economies in the world are trying to describe what they are best at when it comes to digital convergence, and create strategies and compete with each other.

The presented interpretation of the indicated issue is the basis for an attempt to introduce a new concept of technological impact in the environment in which technology is harnessed to work. The technological impact can be presented as the causative effect of the technology acceptance process that determines the functioning and behavior of social, economic and political models in the environment in which this process takes place.

Undoubtedly, the broadly understood technology is a catalyst for human and industrial development. The time of pioneering steam propulsion, the Cincinnati meat processing line, the Harry Ford production line, the Modicon 084 logic controller are undoubtedly the spark that set off the land of great industrial revolutions in human history (Paska, 2017).

Looking through the lens of history, we can also see successes that have been supported by the technological achievements of the current years. The ethical business challenges were noticed by George (2003), which are the clear result of introducing computer and information technologies to business (George, 2003). The business world and economic models also resonate with the process of accepting technology and using it for established benefits. In a pilot study on the process of technology acceptance, carried out by Tworek and Paska (2020), the authors stated that technology acceptance determines the degree of effectiveness of modern organizations. In another publication, Paska (2019) states that access to new 
technologies and its dynamic development increase the perimeter of the boundaries of innovative space in which manufacturing companies, for justified economic reasons, have a chance to implement their processes more effectively.

Ethics that deals with emerging technologies is of interest to a much wider population also beyond the ethical community. Munoko, Brown-Liburd, and Vasarhelyi (2020) note that academia, professionals, policy makers and developers of these technologies are increasingly aware of the legitimate ethical concerns arising from the use of these technologies.

\section{Ethics and Technology}

The one of the important issues that results from the interaction and dependence between man and technology is developing issue of ethics and trust to technology (Wernaart, 2021; Sarbadhikari \& Pradhan, 2020; Kapeller et al., 2020; Kuc-Czarnecka \& Olczyk, 2020; Tavani, 2015). According to Stahl, the concept of ethics is even more controversial and open than the concept of AI (Stahl, 2021). The implemented technology is undoubtedly what helps society to function better and more effectively. Ethical perspectives on information processing and the use of new technologies are needed (Hildebrandt, 2015). Technology helps to operate more efficiently in many aspects and on many different levels of human life. Through the influence of technology on our lives, arises this foundation for raising relevant and important questions, whether a technology such as artificial intelligence can be ethical? (Funk, 2020). If does and technology can be ethical, then what does it mean that technology is ethical? Perhaps the scientists' questions should be asked quite differently. Maybe the issue of ethical technology is an elusive subject. Only because the ethicality of technology in this matter remains beyond the possibility and opportunity to accurately measure it. Or, a person has not yet developed the appropriate tools to answer the question posed. However, it can definitely be said, even though the ethical aspects of technology remain elusive, impossible to measure or calculate accurately, technology can and do have an impact on everyone's life.

It can be stated quite intuitively that good technologies are those that support the values respected and nurtured in communities. One of these values is harmony (Berberich et al., 2020). In this regard, ethics is concerned with assessing to what extent and how technology contributes to the harmonization process (Zhu, 2020). Without a doubt, technology is the tool that determines how people interact with each other on a daily basis. Technology today plays an extremely important role in every society. Unfortunately, it is not transparently visible whether technology has a positive or negative impact on the world and how it actually affects our daily lives. Technology has a particularly high level of interpretive flexibility, which means that it is difficult to predict how it ultimately will be used (Stahl, 2021). This is what makes it so important to undertake research and discussions towards defining the principles and ethical framework for technology (Lütge et al., 2020; Stokes \& Palmer, 2020; Shneiderman; 2020; Hagendorff, 2020; Buruk et al., 2020).

Paraphrasing the words of Sophocles "Nothing vast enters the life of mortals without a curse" - can also be expressed as the perspective of using technology (as something vast), which, apart from its advantages, is also a source of danger, flaws, conflicts or ethical challenges. The ethical challenges that attract the attention of scientists are may be invisible 
in their consequences. This could be a time when the effects of an adapted technology may still be beyond our attention and for common human understanding.

Taught by experience, we know that the society of every civilization was much better at inventing tools than using them wisely. It is much easier for us to build power plants than to precisely describe each impact of this action on the functioning ecosystem and nature. However, we have entered an era in which we are already able to use technology that have a huge impact not only on our private life or professional life, but on the entire functioning of the ecosystem and nature.

The use of technology also resonates with great responsibility for its application. Perhaps it should even be emphasized that responsibility for this technology should be present even before the design stage. Modern engineers or programmers should be ethically prepared. Ethics courses should run parallel with their full education. At this point, Azimov's robotics code and principles are no longer just a futuristic novel, and perhaps provide the first ethical lessons. (Asimov, 1950)

An important aspect emphasized by undertaking research on the ethics of technology is the state of social competences that are related to technology. Society, in a collective perspective, in terms of technology development remains at a distance - which means that people may not understand how artificial intelligence works, but will participate in the consequences of its use, more or less consciously. It means that the algorithms that will have a chance to shape our everyday life will be able to make decisions for us - apart from our awareness of these things.

In many of Professor Harari's lectures, we can learn that biotechnology and information technology will give man the opportunity and power to influence the world inside of us (biochemical processes) and transform ourselves (Harari, 2018). Undoubtedly, creators and users need to realize that they are confronting the ethical use of technology with consequences. In this activity, there is a difficulty in assessing and grasping the challenges that new technologies bring us. And it has a global dimension. Technology, machine learning and artificial intelligence is what, in terms of ethics and more, can have a huge impact on the lives of each of us.

One of the most popular and frequently asked ethical questions in the relationship between technology and man is the question related to work and employment. Will the new technology take away our jobs? So there is an issue related to the form of the social security system, legal, political and economic issues. How will the day of a row worker in a factory look like when technology becomes unbeatable? When technology takes over every trade. The answer to this question is still the blurry picture that futurists deal with.

However, this risk is discussed in the largest economic forums of our globe. There is a risk that the industrial revolution, the development of automation, robotization, and harnessing artificial intelligence to work may remove billions of people from the labor market in the coming decades. Such a movement in society, in the voice of Harari (2018), may contribute to the emergence of a huge new, useless class, which will lead to social, economic and political changes. In other words, it could be argued that the concern is perfectly valid 
that technology could directly displace certain workers from their jobs, thereby reducing the need for their manpower (Goos et al., 2019).

There is also a voice that counters such or similar statements. A defense shield for such fears are the parallels that took place in the nineteenth century. At that time, it was feared that the first forms of automated processes would be a source that would take the work of a significant proportion of employees. It is true that work which in its nature is routine work of repeating the same actions is actually being replaced by robots. Modern factories are filled with automated production processes, which has become commonly understood, for example due to economic conditions, in which such decisions lead to an increase in the efficiency of a production company. Ultimately, human work, regardless of the industry and profession, will most likely be replaced by an automated process - it is, in a way, a threat of future automation argued by the continuous development of machine learning and robotics. Robotics, which is supposed to replace humans and contribute to the creation of a new class of workers that will be economically irrelevant, may additionally be driven by the lack of mental resilience of human in the process of these transformations.

The experience of previous years of industrial revolutions also raises some optimism. In fact, many professions and jobs have been replaced by technology in its broadest sense. However, exactly the same technology is creating new jobs that were not there before the development of this technology. The key to the ethical relationship between technology and man is the adoption of a strategy and policy of action that puts the human being first, not the workplace. A model should be developed that follows the principle that people must be protected, not jobs.

Another ethical aspect of the impact of technology on the employee is the issue of human ability to adapt to the new conditions that the technology will create. New technology can indeed be a way of creating new jobs as it was in history. However, there is a challenge that the mere consequence of placing an employee in a new area of duties may be easier than the actual adaptation of the employee in terms of his competences, skills and abilities. The new technology should also be equated with the need to support the competences and skills of employees that go beyond the current event horizon (Paska, 2019). Another important issue of ethics and technology appears to be very sensitive and delicate when discussion takes place about the use of technology in military services (Agreda, 2020).

\section{Ethical Framework as a Result of Technology Development}

The dynamics of technology development leaves man behind and his actions in terms of responding to the impact of technology on human life. However, the European Union's venture allowed the publication on April 8, 2019 of the first principles and ethical framework for artificial intelligence, which are the result of the work of the European Commission. The publication consists of rules recommended by an independent group of fifty-two experts. This group includes scientists, lawyers and business practitioners, among others. The first version of this document was published on December 18, 2018 and was the subject of an open consultation with over 500 participants providing feedback. The purpose of the document is to promote a technology that can be trusted: artificial intelligence. According to the 
commission, this technology should remain legal, ethical and solid both in terms of social and political conditions (European Commission, 2019). Another document that should be mentioned here, is the European Commission's "Ethics Guidelines for Trustworthy AI" (Pekka et al., 2018).

The actions taken by the European Commission provide further evidence that new digital technologies are becoming more common in the economy every day. This awareness resonates with the ethical mission that technologies are becoming increasingly capable of performing tasks that previously could only be performed by humans. So their use is becoming more and more common. The presence of technology exposes the expansion of relationships with humans, which is linked by the ethical dimension.

A document issued by the European Commission has gathered up-to-date evidence on the implications of technological innovation in the labor markets based on academic literature. The document presents three key challenges for European labor markets: digitization induces shifts in skill requirements, and workers 'fate in changing labor markets crucially depends on their ability to keep up with the change; digitization is not a purely technological process, but requires an accompanying process of organizational change; digitization comes along with rising shares of alternative work arrangements, due to more outsourcing, standardization, fragmentation, and online platforms (Goos et al., 2019).

Table 1. The impact of digitization on labor markets - main mechanisms. Source: Goos et al. (2019).

\begin{tabular}{|c|l|c|}
\hline Mechanism & Description & Impact \\
\hline Displacement effect & $\begin{array}{l}\text { Machines and technology are becoming more and more capable of } \\
\text { performing increasingly complex and complicated tasks that } \\
\text { previously only humans could perform. The risk is related to the } \\
\text { scenario in which companies will increasingly use technology that } \\
\text { will eventually replace human work. This scenario reduces the } \\
\text { demand for manpower. }\end{array}$ & $\begin{array}{c}\text { Reduces the } \\
\text { need for labor }\end{array}$ \\
\hline Productivity effect & $\begin{array}{l}\text { Adaptation of new technology implies a growing demand for new } \\
\text { knochines and intangible capital, which increases the demand for } \\
\text { implementation, maintenance and modernization of applied } \\
\text { technologies. This increases the demand for labor. }\end{array}$ & $\begin{array}{c}\text { Increases the } \\
\text { demand for } \\
\text { labor }\end{array}$ \\
\hline Capital & $\begin{array}{l}\text { Adaptation of new technology implies a growing demand for new } \\
\text { machines and intangible capital, which increases the demand for } \\
\text { knowledge-based tasks and for tasks related to the production, } \\
\text { implementation, maintenance and modernization of applied } \\
\text { technologies. This increases the demand for labor. }\end{array}$ & $\begin{array}{c}\text { Increases the } \\
\text { demand for } \\
\text { accumulation effect }\end{array}$ \\
\hline $\begin{array}{l}\text { New technologies encourage the creation of new jobs for employees } \\
\text { for two reasons: First, displacing employees from old jobs means } \\
\text { there are more employees who can take over new, more productive } \\
\text { jobs. Second, new machines and the growth of knowledge capital } \\
\text { may directly require new tasks (eg, machine operation) or enable } \\
\text { new tasks (eg, working on a platform). Creating new tasks directly } \\
\text { counteracts the effect of displacements, increasing the demand for } \\
\text { labor. }\end{array}$ & $\begin{array}{c}\text { Increases the } \\
\text { demand for } \\
\text { labor }\end{array}$ \\
\hline
\end{tabular}

The challenges presented in the European document require appropriate policy responses at European, national and regional level. It is therefore justified to undertake activities aimed at reflecting on the impact of technological progress on the labor market. The 
groundbreaking contribution of Acemoglu and Resrepo allows for the presentation of the impact of digitization on labor markets, which is presented in Table 1 above.

However, in the publication by Hagendorff (2019), he points out that the ethics of the smart intelligentsia very often fails. The author emphasizes that there is no reinforcing mechanism. Additionally, it points out that when ethics is integrated with institutions, it only serves as a marketing strategy. The author concludes that reading ethical guidelines has no significant impact on developers' decision making (Hagendorff, 2019) The researcher says that the ethical guidelines have no impact on human decision-making in the field of artificial intelligence and machine learning.

Leading companies in technology development see technology, machine learning or artificial technology as tools embedded in everyday life, in business, administration, medicine and other industries. Such enterprises should be distinguished by the adopted policy regarding the implementation of artificial intelligence by implementing ethical principles in applications and processes of artificial intelligence. Then only such systems can be systems built on principles based on trust. Some of the most important ethical factors that can be seen as the foundations of a trustworthy system are: explainability, fairness, robustness, transparency, privacy (Doorn, 2020; Parker et al., 2019; Davis, 2005; Winfield \& Jirotka, 2018; Jobin et al., 2019; Robinson, 2020; Larsson \& Heintz, 2020) Another ethical challenge in the field of technology development is the need to broaden the approach to digital ethics, bringing together a range of cultural, social and structural perspectives on ethical issues related to the use of technology (Aggarwal, 2020; Hongladarom \& Ess, 2007).

\section{Conclusions}

It is important to emphasize that technology reliability is a key aspect of the reliability of modern organizations (Tworek et al., 2020). Technology is able to increase efficiencies, provide greater insight into business processes, and create competitive advantages for adopters. With that said, there are some ethical concerns with the technology, which, if left unresolved, could negate the anticipated benefits (Munoko et al., 2020).

The article is an attempt to raise an interesting issue and focus on ethical aspect of using technology that is present in the business and private space. The content aims to provoke reflection on the causative effects of technology in the field of ethics that accompanies the process of technology acceptance. The content of the article emphasizes the essence of ethics in the space of technology development. Undoubtedly, technology is changing the face of modern businesses. The scope of the literature analysis on this subject shows that the aspects of technology are not given much attention in this regard (Doorn, 2019). Along with this change, it is important to adopt appropriate roles and rules which will be consistent with the established ethics policy. The review of the literature on the subject makes it possible to identify the needs to start and conduct research that integrates ethics with technology. As it was pointed out by Hagendorff (2019) there is crucial calls for applied ethics, which are meant to harness the "disruptive" potential of new technologies. It is important to identify the right research directions that will allow to define ethical technology in the business space. 
The content of the article indicates the need to support ethics in terms of adopting legal framework conditions and establishing appropriate technology audit mechanisms (Munoko et al., 2020). It is also important to implement appropriate curricula at universities in order to improve skills and competences related to the integration of technology and ethics (Antoniou, 2021; McDonald \& Pan, 2020). Stahl and his research team (2021), combining technology with ethics, distinguish research directions: related to the application of machine learning, social and political issues arising from the use of technology, and the study of the nature of reality and humanity.

The article encourages to understand and evaluate ethics perceptions and possible management mechanisms that could be used to solve ethical problems. It is an aspect of research that permeates the socio-economic, cultural and political context that determines the image of society (Cath, et al., 2016). Undoubtedly, the combination of technology and ethics should be based on the foundation and goal, which is to create a technology that follows an ideal ethical principle or set of ethical principles in guiding its behavior (Anderson, 2011). The development of technology and its range of possibilities explains the need to establish precise guidelines at many levels of functioning society (Buruk et al., 2020). It is clear that content of article is the very basis for further work.

\section{References}

Aggarwal, N. (2020). Introduction to the Special Issue on Intercultural Digital Ethics. Philosophy E Technology, 33, 547-550. https://doi.org/10.1007/s13347-020-00428-1

Agreda, A. G. (2020). Ethics of autonomous weapons systems and its applicability to any AI systems.

Telecommunications Policy, 44, 101953. https://doi.org/10.1016/j.telpol.2020.101953

Ajzen, I., \& Fishbein, M. (1980). Understanding Attitudes and Predicting Social Behavior. NJ: Prentice Hall.

Anderson, S.L. (2011). Machine metaethics. In M. Anderson, \& S. L. Anderson (Eds.), Machine ethics (pp. 21-27). https://doi.org/10.1017/CBO9780511978036.004

Antoniou, J. (2021). Dealing with Emerging AI Technologies: Teaching and Learning Ethics for AI. In Quality of Experience and Learning in Information Systems. EAI/Springer Innovations in Communication and Computing. Springer, Cham. https://doi.org/10.1007/978-3-030-52559-0_6

Asimov, I. (1950). The Evitable Conflict. Street \& Smith.

Bandura, A. (1986). Social Foundations of Thought and Action: A Social Cognitive Theory. Englewood Cliffs, NJ: Prentice- Hall Inc

Berberich, N., Nishida, T., \& Suzuki, S. (2020). Harmonizing Artificial Intelligence for Social Good. Philosophy E Technology, 33, 613-638. https://doi.org/10.1007/s13347-020-00421-8

Buruk, B., Ekmekci, P. E., \& Arda, B. (2020). A critical perspective on guidelines for responsible and trustworthy artificial intelligence. Medicine, Health Care and Philosophy, 23, 387-399. https://doi.org/10.1007/s11019-02009948-1

Büchi, G., Cugno, M., \& Castagnoli, R. (2020). Smart factory performance and Industry 4.0. Technological Forecasting \& Social Change, 150, 119790. https://doi.org/10.1016/j.techfore.2019.119790

Buer, S. (2018). The link between Industry 4.0 and lean manufacturing: mapping current research and establishing a research agenda. Journal International Journal of Production Research, 56(8). https://doi.org/10.1080/00207543.2018.1442945

Char, D. S., Shah, N. H., \& Magnus, D. (2018). Implementing machine learning in health care - addressing ethical challenges. N. Engl, J. Med., 378, 981-983. https://doi.org/10.1056/NEJMp1714229

Cath, C. J. N., Wachter, B., Mittelstadt, B., Taddeo, M., \& Floridi, L. (2016). Artificial Intelligence and the “Good Society": The US, EU, and UK Approach. Social Science Research Network. https://doi.org/10.1007/s11948017-9901-7

Davis, F. (1989). Perceived Usefulness, Perceived Ease of Use, and User Acceptance of Information Technology. MIS Quarterly, 319-339. https://doi.org/10.2307/249008 
Davis, F., Bagozzi, R., \& Warshaw, P. (1992). Extrinsic and Intrinsic Motivation to Use Computers in the Workplace. Journal of Applied Social Psychology, 22(14), 1111-1132. https://doi.org/10.1111/j.15591816.1992.tb00945.x

Davis, M. (2005). Engineering Ethics. Ashgate Publishing.

Diez-Olivan, A., Del Ser, J., Galar, D., \& Sierra, B. (2019). Data Fusion and Machine Learning for Industrial Prognosis: Trends and Perspectives towards Industry 4.0. Information Fusion, 50, 92-111. https://doi.org/10.1016/j.inffus.2018.10.005

Directorate-General for Communications Networks, Content and Technology (European Commission). (2019). Grupa ekspertów wysokiego szczebla ds. sztucznej inteligencji 2019.

Doorn, N. (2020). Artificial intelligence in the water domain: Opportunities forresponsible use. Science of Total Environment, 755. https://doi.org/10.1016/j.scitotenv.2020.142561

Ejdys, J. (2018). Zaufanie do e-commerce. Oficyna Wydawnicza Politechniki Białostockiej, Białystok.

European Commission. (2019). European Commission's High-Level Expert Group on Artificial Intelligence. Ethics guidelines for trustworthy AI. Brussels: European Commission. https://ec.europa.eu/futurium/en/ai-allianceconsultation

Funk, M. (2020). What Is Robot Ethics? ...And Can It Be Standardized? Frontiers in Artificial Intelligence and Applications, 335, 469-480.

Gajsek, B., Marolt, J., Rupnik, B., Lerher, T., \& Sternad, M. (2019). Using Maturity Model and Discrete-Event Simulation for Industry 4.0 Implementation. International Journal of Simulation Modelling, 18(3), 488-499. https://doi.org/10.2507/IJSIMM18(3)489

George, R. (2003). The ethics of information technology and business. Malden: Blackwell Publishing.

Goos, M., Arntz, M., Zierahn, U., Gregory, T., Carretero, G., Gonzalez, V., \& Jonkers, K. (2019). The impact of Technological innovation on the Future of Work. EUR - Scientific and Technical Research Reports, Information Society Innovation and growth. https://ec.europa.eu/jrc/sites/jrcsh/files/jrc117212.pdf.

Harari, Y. N. (2017). Reboot for the AI revolution. Nature, 550, 324-327. https://doi.org/10.1038/550324a

Hagendorff, T. (2019). The ethics of AI Ethics: an evaluation of guidelines. https://arxiv.org/ftp/arxiv/papers/1903/1903.03425.pdf

Hagendorff, T. (2020). Publisher Correction to: The Ethics of AI Ethics: An Evaluation of Guidelines. Minds and Machines, 30. https://doi.org/10.1007/s11023-020-09517-8

Hildebrandt, M. (2015). Smart Technologies and the End(s) of law. Cheltenham, Edward Elgar.

Hochuł, A.(2017). Identyfikacja źródeł innowacynjych możliwości przedsiębiorstwa 4.0. In L. Kowalczyk, \& F. Mroczko (Eds.), Innowacyjność to cyfryzacja i rozwój, Wałbrzych: Prace Naukowe Wyższej Szkoły Zarzadzania I Przedsiębiorczości.

Hongladarom S., \& Ess. C. (2007). Information technology ethics: cultural perspectives. Idea Group Reference.

Hozdic, E., Kozjek, D., \& Butala, P. (2020). A Cyber-Physical Approach to the Management and Control of Manufacturing Systems. Strojniški vestnik - Journal of Mechanical Engineering, 66(1), 61-70.

Jobin, A., Marcello, L., \& Vayena, E. (2019). The global landscape for AI ethics guidelines. Nature Machine Intelligence, 1, 389-399. https://doi.org/10.1038/s42256-019-0088-2

Kapeller, A., Gelzmann, H., Fosh-Villaronga, E., \& Hughes, A. (2020). A Taxonomy of Ethical, Legal and Social Implications of Wearable Robots: An Expert Perspective. Science and Engineering Ethics, 26, 3229-3247. https://doi.org/10.1007/s11948-020-00268-4

Kowalczyk, L. (2017). Cyfryzacja w procesie postępu cywilizacyjnego i jej współczesna rola w innowacyjności. In L. Kowalczyk, \& F. Mroczko (Eds.), Innowacyjność to cyfryzacja i rozwój, Wałbrzych: Prace Naukowe Wyższej Szkoły Zarządzania I Przedsiębiorczości.

Kuleshov, A., Ignatiev, A., Abramova, A., \& Marshalko, G. (2020). Addressing AI ethics through codification. In Proceedings - 2020 International Conference Engineering Technologies and Computer Science, EnT 2020, 9140627 (pp. 24-30). https://doi.org/10.1109/EnT48576.2020.00011

Larsson, S., \& Heintz, F. (2020). Transparency in AI. Internet Policy Review, 9, 1-16. https://doi.org/10.14763/2020.2.1469.

Lütge, C., Poszler, F., Acosta, A., Danks, D., Gottehrer, G., Miher-Popa, L., \& Neseer, A. (2021). AI4People:Ethical Guidelines for the Automotive Sector - Fundamental Requirements and Practical Recommendations. International Journal of Technoethics, 12(1). https://doi.org/10.4018/IJT.20210101.oa2

Kuc-Czarnecka, M., \& Olczyk, M. (2020). How ethics combine with big data: a bibliometric analysis. Humanities and Social Sciences Communications, 7, 137. https://doi.org/10.1057/s41599-020-00638-0 
McDonadl, N., \& Pan, S. (2020). Intersectional AI: A Study of How Information Science Students Think about Ethics and Their Impact. In Proceedings of the ACM on Human-Computer Interaction, 4. https://doi.org/10.1145/3415218.

Miller, B. (2020). Is Technology Value-Neutral? Science, Technology \& Humal Values, 46(1), 53-80. https://doi.org/10.1177/0162243919900965

Monostori, L., Kada, B., Bauernhansl, T., Kondoh, S., Kumara, S., Reinhart, G., Sauer, O., Schuh, G., Sihn, W., \& Ueda, K. (2016). Cyber-physical systems in manufacturing. CIRP Annals - Manufacturing Technology, 65, 621-641. https://doi.org/10.1016/j.cirp.2016.06.005.

Munoko, I., Brown-Liburd, H., \& Vasarhelyi, M. (2020). The Ethical Implications of Using Artificial Intelligence in Auditing. Journal of Business Ethics, 167, 209-234. https://doi.org/10.1007/s10551-019-04407-1

Park, S. H., Kim, Y. H., Lee, J. Y., Yoo, S., \& Kim, C. J. (2019). Ethical challenges regarding artificial intelligence in medicine from the perspective of scientific editing and peer review. Science Editing, 6, 91-98.

Paska, M. (2017). Inteligentne fabryki i ich technologia. In L. Kowalczyk, \& F. Mroczko (Eds.), Innowacyjność to cyfryzacja i rozwój. Wałbrzych: Prace Naukowe Wyższej Szkoły Zarządzania I Przedsiębiorczości.

Paska, M. (2019). Inżynieria produkcji - bezpieczeństwo i ewaluacja zautomatyzowanych procesów produkcyjnych. In L. Kowalczyk, \& F. Mroczko (Eds.), Kreatywność i innowacyjność w zarzadzaniu i pedagogice w erze cyfrowej. Wałbrzych: Prace Naukowe Wyższej Szkoły Zarządzania i Przedsiębiorczości.

Pekka, A.-P., Bauer, W., Bergmann, U., Bieliková, M., Bonefeld-Dahl, C., Bonnet, Y., \& Bouarfa, L. (2018). The European Commission's high-level expert group on artificial intelligence: Ethics guidelines for trustworthy AI. Working Document for stakeholders' consultation. Brussels (pp. 1-37).

Raab, C. (2020). Information privacy, impact assessment, and the place of ethics. Computer law $\mathcal{E}$ security review 37, 105404. https://doi.org/10.1016/j.clsr.2020.105404

Robinson, S. C. (2020). Trust, transparency, and openness: How inclusion of cultural values shapes Nordic national public policy strategies for artificial intelligence (AI). Technology in Society, 63, 101421. https://doi.org/10.1016/j.techsoc.2020.101421

Ryan, M. (2020). In AI We Trust: Ethics, Artificial Intelligence, and Reliability. Science and Engineering Ethics, 26, 2749-2767. https://doi.org/https://doi.org/10.1007/s11948-020-00228-y

Sarbadhikari, S., \& Pradhan, K. (2020). The Need for Developing Technology-Enabled, Safe, and Ethical Workforce for Healthcare Delivery. Safety and Health at Work, 11, 533-536. https://doi.org/10.1016/j.shaw.2020.08.003

Shneiderman, B. (2020). Bridging the gap between ethics and practice: Guidelines for reliable, safe, and trustworthy human-centered AI systems. ACM Transactions on Interactive Intelligent Systems, 10, 26.

Stahl, B. C., Andreou, A., Brey, P., Hatzakis, T., Kirichenko, A., Macnish, K., Laulhe Shaelou, S., Patel, A., Ryan, M., \& Wright, D. (2021). Artificial intelligence for human flourishing - Beyond principles for machine learning. Journal of Business Research, 374-388. https://doi.org/10.1016/j.jbusres.2020.11.030

Stokes, F., \& Palmer, A. (2020). Artificial Intelligence and Robotics in Nursing: Ethics of Caring as a Guide to Dividing Tasks Between AI and Humans. Nursing Philosophy, 21. https://doi.org/10.1111/nup.12306.

Taylor, S., \& Todd, P. A. (1995). Understanding Information Technology Usage: A Test of Competing Models. Information Systems Research, 6(4), 144-176. https://www.jstor.org/stable/23011007

Tavani, H. (2015). Levels of Trust in the Context of Machine Ethics. Philos. Technol., 28, 75-90. https://doi.org/10.1007/s13347-014-0165-8

Thompson, R. L., Higgins, C. A., \& Howell, J. M. (1991). Personal Computing Toward a Conceptual Model of Utilization. MIS Quarterly 15(1), 125-143. https://www.jstor.org/stable/pdf/249443.pdf

Tworek, K., Bieńkowska, A., \& Zabłocka-Kluczka, A. (2020). Organizational reliability: Human resources, information technology and management. Routledge.

Tworek, K., \& Paska, M. (2020). Technology acceptance influence on performance of manufacturing organizations. In Khalid S. Soliman (Ed.), Proceedings of the 35th International Business Information Management Association Conference (IBIMA): 1-2 April 2020, Seville, Spain (pp. 7996-8007). International Business Information Management Association.

Wernaart, B. (2021). Developing a roadmap for the moral programming of smart technology. Technology in Society, 64. https://doi.org/10.1016/j.techsoc.2020.101466

Venkatesh, V., Morris, M. G., Davis, G. B., \& Davis, F. D. (2003). User acceptance of information technology: Toward a unified view. MIS Quarterly, 27(3), 425-478. https://www.jstor.org/stable/pdf/30036540.

Qin, Z. (2020). Ethics, society, and technology: A Confucian role ethics perspective. Technology in Society, 63, 101424. https://doi.org/10.1016/j.techsoc.2020.101424 